Case Report

\title{
Osteoid osteoma in a metacarpal bone: literature review and case report
}

\section{María de los Angeles Mendoza Vélez*, Marco Aurelio Rendon Medina, Erik Hanson Viana, Jorge Arturo Rojas Ortiz, Ricardo Pacheco Lopez}

Plastic and Reconstructive Surgery Department of Hospital General Dr. Ruben Leñero, Mexico

Received: 20 January 2022

Accepted: 09 February 2022

\section{*Correspondence:}

María de los Angeles Mendoza Vélez,

E-mail: mangelesmendozav@gmail.com

Copyright: () the author(s), publisher and licensee Medip Academy. This is an open-access article distributed under the terms of the Creative Commons Attribution Non-Commercial License, which permits unrestricted non-commercial use, distribution, and reproduction in any medium, provided the original work is properly cited.

\begin{abstract}
Osteoid osteomas are benign skeletal tumors; more than half of the lesions occur in lower extremity long bones, with very few cases reported in metacarpal bones. We presented the case of a patient at the plastic surgery department of a regional hospital, who presented with a tender tumor in the left hand over the past 2 years.
\end{abstract}

Keywords: Osteoid osteoma, Bone tumor, Hand surgery, Bone graft

\section{INTRODUCTION}

Osteoid osteoma was first described by Bergstrand in 1930 and characterized by Jaffe as an entity in $1935 .^{1}$ Osteoid osteoma is the third most common (after osteochondromas and no ossifying fibromas) and corresponds to $11 \%$ of the benign bone tumors. With only 6 to $13 \%$ of osteoid osteomas affecting the hand and wrist region. ${ }^{2-5}$ It is most commonly seen in the second and third decades of life, although patients as young as three years old have been reported. There is a male to female preponderance of 3 to $1 .{ }^{6}$ It may present with various clinical presentations; although small, it can produce significant pain and discomfort for prolonged periods that usually worsens at night and is relieved by salicylates. Radiography and computed tomography scans are the mainstays of imaging diagnosis.

Osteoid osteomas are small, distinctive, no progressive, benign osteoblastic lesions consisting of a nidus surrounding sclerotic bone. Differential diagnosis covers an extensive range of conditions due to its variety of presentations. The natural history is for regression within 6 to 15 years with no treatment; however, this can be reduced to 2 to 3 years using aspirin and non-steroidal anti-inflammatory drugs. Computed tomography-guided percutaneous techniques including trephine excision, cryoablation, radiofrequency ablation and laser thermocoagulation. ${ }^{6}$ Its pathology and pathogenesis have not been clearly defined, its radiological features can imitate other etiologies and surgical treatment is not always successful. ${ }^{6}$ A literature review reveals that very few cases of metacarpal osteoid osteoma have been reported. Here we presented a rare case of osteoid osteoma of a metacarpal bone that presented with an extensive tumor lesion.

\section{CASE REPORT}

A seventeen year old female presented to the plastic surgery department, referring no allergies or any associated disease, with a history of two years of dull pain associated with a volume augmentation in the left hand, without any trauma history. On examination, the overlying skin was healthy with minor local swelling of the fifth metacarpal bone of the left hand. There was tenderness over a palpable mass of approximately $4 \times 3$ $\mathrm{cm}$, of hard consistency, nonmobile, no limitations in movement or any sensitivity alteration were noticed (Figure 1). Radiographs revealed an expansible, eccentric 
lesion seen in the proximal diaphysis and base of the fifth metacarpal (Figure 2a). Laboratory findings were normal; radiographically, we observed bone hypertrophy in the fifth metacarpal bone at the base level. MRI showed a focal lesion and the bone had a high-intensity area (Figure 2b). After complete workup, the patient was posted for surgical exploration. We found a bone tumor on the diaphysis and base of the proximal fifth left metacarpal bone (Figure $3 \mathrm{a}$ and $\mathrm{b}$ ). We proceeded to complete the tumor resection and harvested an iliac crest corticocancellous bone graft; miniplate fixation was made with a 10-hole 2.0 system (Figure $3 \mathrm{c}$-e). The patient showed a good outcome, with good rehabilitation, presented with a small hypertrophic scar (Figure 4 a-b).

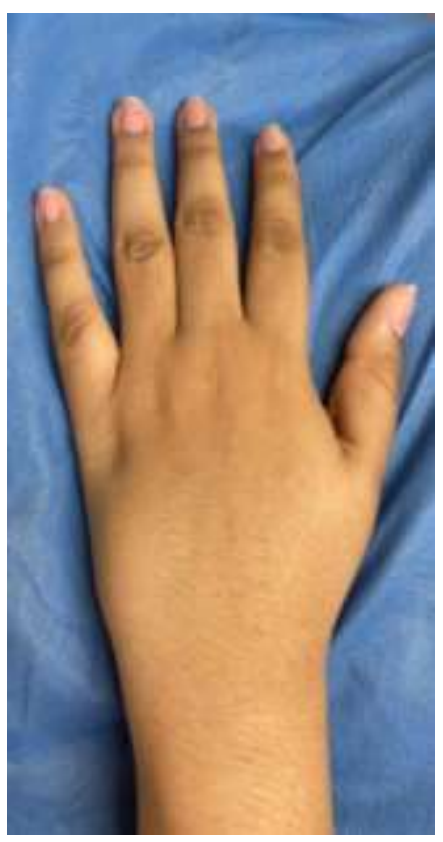

Figure 1: Painful swelling of the proximal segment of the fifth metacarpal.

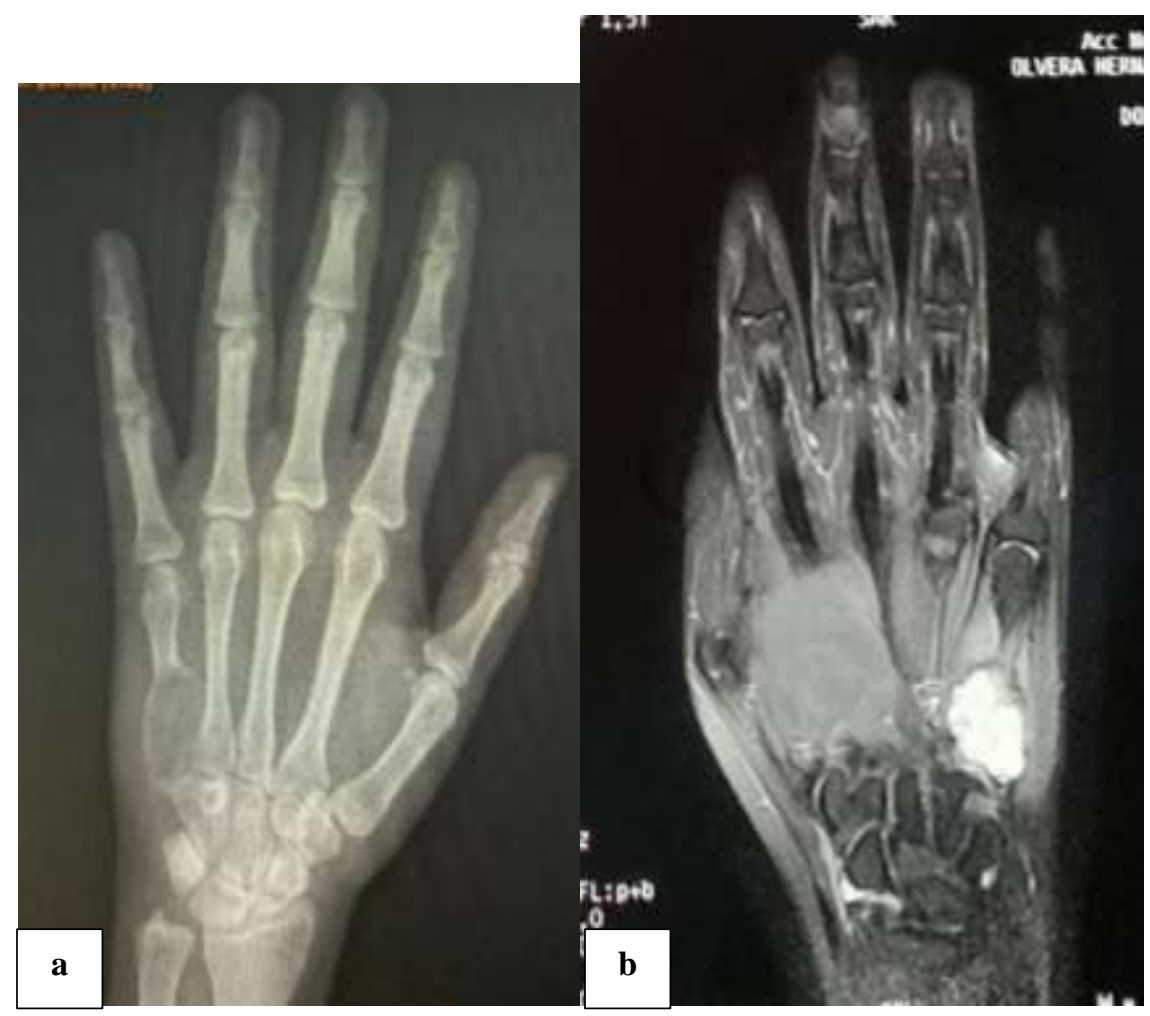

Figure 2: (a) Anteroposterior plain radiograph of hand showing lesion with cortical sclerosis in the base and proximal half of the fifth metacarpal; (b) MRI image showing well-defined eccentric lesion in the base of fifth metacarpal showing a hyperintense signal on $\mathrm{T} 2$ image. 


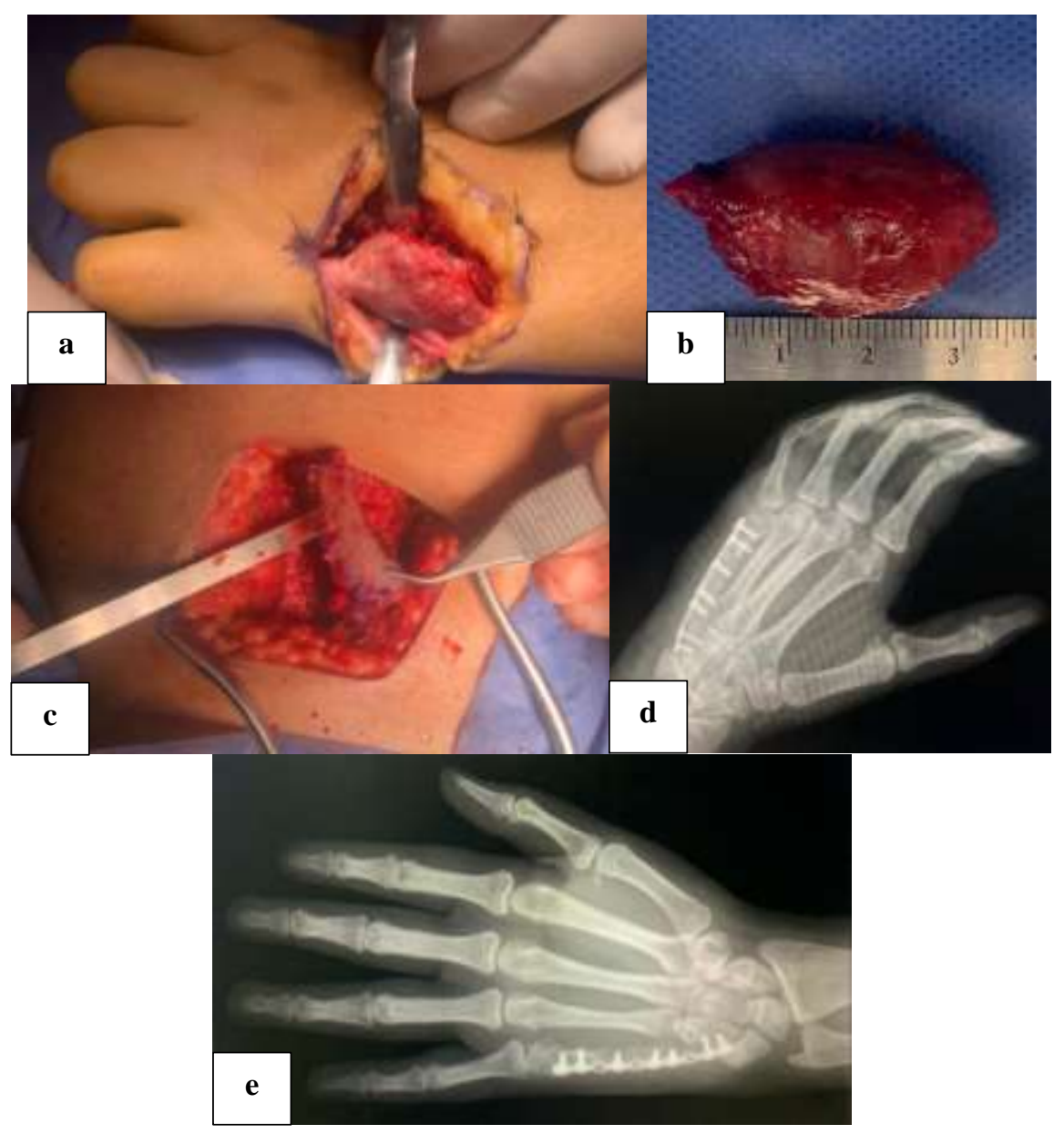

Figure 3: (a) The dorsal approach of the fifth metacarpal with exposure of the lesion; (b) resection of the proximal fifth metacarpal bone, $35 \times 21 \mathrm{~mm}$; (c) a iliac crest bone graft of $35 \times 12 \mathrm{~mm}$; (d and e) postoperative radiographs showing a ten-hole 2.0 system miniplate reducing the iliac bone graft with the distal fifth metacarpal and the Hamate.

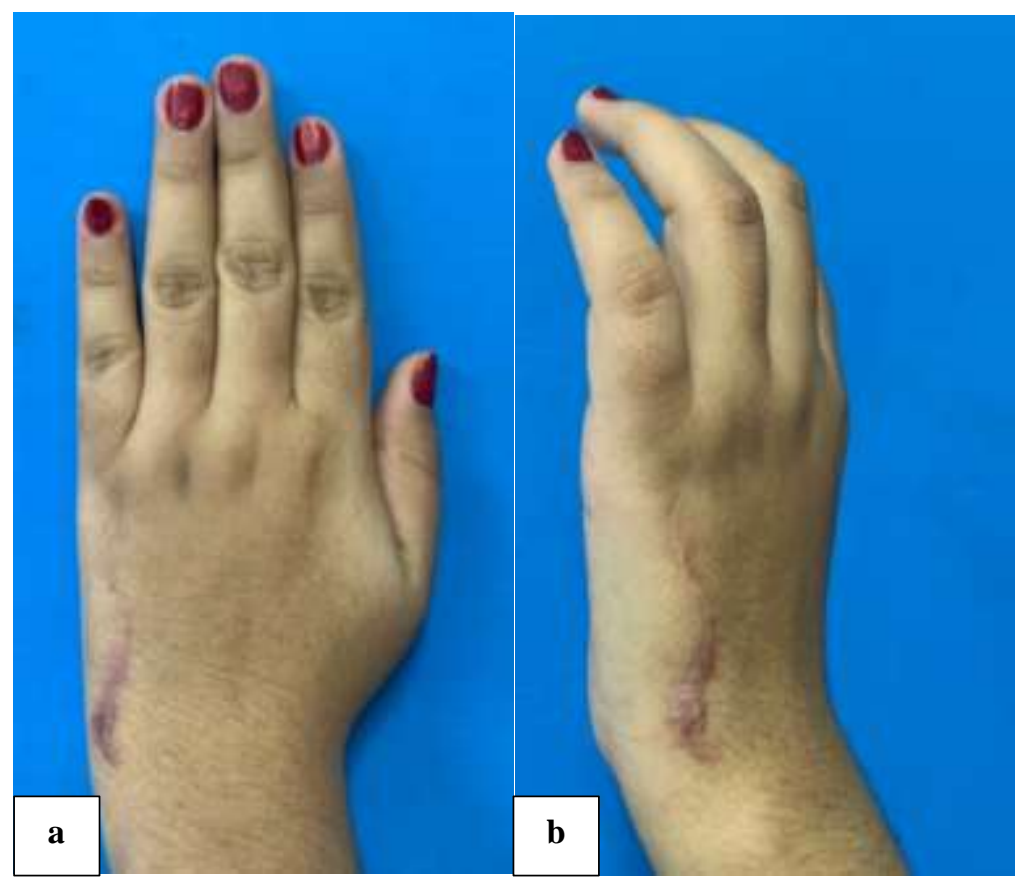

Figure 4: Surgical scar in the three-months follow up consult; (a) dorsal view; (b) oblique view. 


\section{DISCUSSION}

The pathogenesis of osteoma osteoid remains controversial. Jaffe et al believed in a neoplastic origin, others on an inflammatory basis, and some suggested it to be an unusual healing and reparative process. However, its growth was not typical and, in some cases, spontaneous regression and healing occurred. ${ }^{6-10}$

Osteoid osteomas were benign skeletal tumors characterized by an intracortical nidus with variable amounts of calcification, sclerosis and bone marrow edema. ${ }^{11,12}$ More than half of the lesions occurred in long bones of the lower extremity, with the proximal femur being the most common location. In the spine, osteoid osteomas almost exclusively occurred in the posterior vertebral elements. ${ }^{13}$ Currently, the precise nature of the lesion remained undetermined. Imaging played a significant role in the detection of these lesions and it rarely localized in the carpal or metacarpal bones. ${ }^{13,14}$

The most frequent presentation sites in hand were the phalanges and carpal bones and the least commonly found in the metacarpal bones. ${ }^{15-17}$ So, when a metacarpal presentation was found, the differential diagnosis should include syphilitic dactylitis, tuberculosis, other infection, brodies abscess, enchondroma, post-traumatic change, osteochondroma, soft tissue tumor, among others. ${ }^{18}$

Many surgical techniques have been described. However, since this tumor usually presented with pain, an early diagnosis was usually encountered. Findings usually presented with small tumors (commonly did not exceed 1 $\mathrm{cm}$ in diameter), so cortical peeling or burr-down with curettage was sufficient. ${ }^{19}$ However, in cases like the one presented, en bloc resection was required, leaving a bone gap that must be reconstructed with a bone graft. Other techniques have been described, like percutaneous curettage, aldolization, laser coagulation, thermoregulation or radiofrequency ablation. ${ }^{20}$ These lesions in the hand region were usually too narrow for the percutaneous treatments. $^{21}$

\section{CONCLUSION}

This case is a rare presentation of a large osteoid osteoma in a metacarpal bone. Usually, an unroofing and curettage method is sufficient for a complete exercise. However, a complete tumor exercise should be done with a bone graft and miniplate reconstruction in a presentation like in this case, where a complete cortical degeneration is presented.

Funding: No funding sources Conflict of interest: None declared

Ethical approval: Not required

\section{REFERENCES}

1. Jaffe HL. B Osteoid-osteoma: a benign osteoblastic tumor composed of osteoid and atypical bone. J Hand Microsurg. 2015;7(1):187-90.

2. Boscainos P, Cousins GR, Kulshreshtha R, Oliver TB. Osteoid osteoma. Orthopedics. 2013;36(10):792-800.

3. Unni KK. Osteoid osteoma. In: Unni KK, eds. Dahlin's Bone tumors: general aspects and data on 11,087 cases. 5th ed. Philadelphia, PA: Lippincott Raven Publishers; 1996: 121-30.

4. Campanacci M. Osteoid osteoma, bone and soft tissue tumours. Padova, Italy: Piccin Nuova Libraria; 1999: 391-414.

5. Lee EH, Sha M, Hui JH. Osteoid osteoma: a current review. J Pediatr Orthop. 2006;26(5):695-700.

6. Lee E, Shafi M, Hui JHP. Osteoid osteoma. A current review. J Pediatr Orthop. 2006;26(5).

7. Jaffe HL, Lichtenstein L. Osteoid-osteoma. J Bone Joint Surg. 1940;22:645-82.

8. Moberg E. The natural course of osteoid osteoma. J Bone Joint Surg Am. 1951;33(1):166-70.

9. Golding JS. The natural history of osteoid osteoma; with a report of twenty cases. J Bone Joint Surg Br. 1954;36(2):218-29.

10. Ghanem I. The management of osteoid osteoma: updates and controversies. Curr Opin Pediatr. 2006;18(1):36-41.

11. Infante-Cossio P, Restoy-Lozano A, Espin-Galvez F, MD, Gonzalez-Perez L. Mandibular osteoid osteoma. J Emerg Med. 2016:1-2.

12. Chai JW, Hong SH, Choi JY, Koh YH, Lee JW, Choi J, et al. Radiologic diagnosis of osteoid osteoma: from simple to challenging findings. Radiographics. 2010;30(3):737-49.

13. Jafari D, Mazhar FN. Osteoid osteoma of the trapezoid bone. Case report. Arch Iran Med. 2012;15(12).

14. Horiuchi K, Horiuchi Y, Ochi K. Osteoid osteoma of the distal phalanx of the ring finger with clubbed finger deformity: a case report. J Hand Surg (AsianPacific). 2017;22(2):248-50.

15. Jafari D, Shariatzade H, Mazha FN, Abbasgholizadeh B, Dashtebozorgh A. Osteoid osteoma of the hand and wrist: a report of 25 cases. Med J Islam Republic Iran. 2013;27(2):62-6.

16. Muren C, Hoglund M, Engkvist O, Juhlin L. Osteoid osteoma of the hand. Report of three cases and review of the literature. Acta Radiol. 1991;32(1):62-6.

17. Burger IM, McCarthy EF. Phalangeal osteoid osteomas in the hand: a diagnostic problem. Clin Orthop Relat Res. 2004;427:198-203.

18. Dick HM. Bone tumors. In: Green DP, eds. Operative hand surgery. New York: Churchill Livingstone; 1982: 1684.

19. Campanacci M, Ruggieri P, Gasbarrini A, Ferraro A, Campanacci L. Osteoid osteoma. Direct visual identification and intralesional excision of the nidus 
with minimal removal of bone. J Bone Joint Surg Br. 1999;81(5):814-20.

20. Cuesta HE, Villagran JM, Horcajadas AB, Kassarjian A, Caravaca GR. Percutaneous radiofrequency ablation in osteoid osteoma: tips and tricks in special scenarios. Eur $\mathbf{J}$ Radiol. 2018;102:169-75.

Cite this article as: Vélez MDLAM, Medina MAR, Viana EH, Ortiz JAR, Lopez RP. Osteoid osteoma in a metacarpal bone: literature review and case report. Int J Res Med Sci 2022;10:740-4. 